\title{
PODSTAWY EPISTEMOLOGICZNE WIARY WE WCZESNYCH PISMACH GABRIELA MARCELA *
}

Filozofia Gabriela Marcela stanowi z pewnością jeden z najważniejszych i najgłębszych rozdziałów współczesnej myśli przenikniętej religią, a także - jak sądzę - współczesnej filozofii w ogóle. Marcel jest być może w ciągu całych dziejów filozofii europejskiej jednym z nielicznych filozofów, u którego splątają się w organiczną całość autentyczny zmysł religijny - co więcej, zmysł specyficznie chrześcijański, a nawet katolicki (jeśli taki istnieje) - wymóg ścisłego myślenia oraz etos zarówno chrześcijański, jak i głęboko ludzki. Należy on do tego typu myślicieli, którzy - jak św. Augustyn, może Pascal, może Kierkegaard, Newman, Husserl — są zarówno mistrzami życia, jak i ostrożnego, otwartego, pytającego i badawczego myślenia. Pod tym ostatnim względem, ale także pod względem uderzających czasem merytorycznych zbieżności upodobnia się on do Martina Heideggera. Myśl Marcela jest trudna pomimo, a może właśnie częściowo z powodu potocznego, nietechnicznego na pozór sposobu pisania. Przyczyn tego jest kilka. Przede wszystkim usiłuje on opisać i poddać badaniu fenomeny dotychczas nie poddawane filozoficznym analizom, same w sobie niełatwe do „wypatrzenia”. Wśród fenomenów tych na pierwsze miejsce zdaje się wysuwać fenomen ,tajemnicy ontologicznej”, który „funduje” wiele innych, a zarazem w nie przenika, i dzięki któremu można zrozumieć, dlaczego ich analizy filozoficzne nie mogą się dokonywać w języku odziedziczonej po wiekach filozofii n a uk ow e j. W tym miejscu, nawiasem mówiąc, widać najlepiej zarówno podobieństwa, jak i rozbieżności w stosunku do Heideggera. Natrafiwszy na analogiczny zespół fenomenów Heidegger dokonał radykalnie odmiennej decyzji językowej: postanowił stworzyć własny, naszpikowany neologizmami, hermetyczny i trudno przyswajalny język; natomiast Marcel „postawił" na język potoczny, całkowicie odciążony od naukowości, w którym wbrew pozorom łatwiej precyzyjnie określić - nie wpadając w specyficzną „literackość”, która stała się udziałem tzw. późnego Heideggera - ludzkie, przednaukowe doświadczenie świata, badane aż do pewnego momentu przez obu myślicieli. Ale tutaj czyha trudność: język po-

* Niniejszy artykuł jest fragmentem przygotowanej do druku książki na temat fillozofii religii u G. Marcela. 
toczny bywa także wieloznaczny, brak mu nieraz klarowności, tak cennej w filozofii. Różne terminy filozofii Marcela opalizują wieloma znaczeniami, przy czym każdy, kto wgłębiał się w jego myśl, musi przyznać jedno: owe wieloznaczności wynikają $\mathrm{z}$ różnego typu o pis u, tzn. $\mathrm{z}$ tego, co z całego nieskończonego bogactwa danego zjawiska (jak np. egzystencja, wierność, nadzieja itp.) jawi się filozofowi w danym momencie. Kłopot w tym, że z wyjątkiem także i pod tym względem cennego dzieła Le mystère de l'être Marcel nie próbował na ogół uzgadniać za sobą różnych znaczeń danego terminu. Stąd rola egzegezy, która została już zresztą w ogromnej mierze dokonana, głównie dzięki podstawowemu i drobiazgowemu dziełu o. Rogera Troisfontaines De l'existence à l'être (Namur Louvain, Paris 1953).

Zagadnienia religii i Boga - zawsze w Jego relacji do człowieka towarzyszą Gabrielowi Marcelowi od początku jego filozofowania. Nie tylko towarzyszą - stanowią motyw przewodni jego myśli. Oto dwa cytaty: „W ciągu lat bezpośrednio poprzedzających wojnę 1914 r. [chodzi tu o początki filozofowania Marcela, przyp. K.T.] intencją moją coraz jaśniej rozpoznawaną było przeprowadzanie badań, których istotnym przedmiotem było oświetlenie, to znaczy uczynienie zrozumiałym porządku afirmacji religijnej, która prezentowała mi się jako niepowątpiewalna, chociaż jawiło mi się coraz jaśniej, że nie należy marzyć o wintegrowaniu jej w system typu heglowskiego" ${ }^{1}$. „[Ewolucja mojej myśli] skierowała się od początku w stronę tego, co można by nazwać pre-mistyką, to znaczy starała się odkryć pewne drogi dojścia do mistyki w ścisłym sensie, ale stopniowo [...] zajęła się zgłębianiem warunków, poza którymi mądrość godna tego miana dąży do zniknięcia, by ustąpić miejsca szaleństwu, które zresztą w pewnych wypadkach może uzyskiwać pozory racjonalne" ". Mądrość ta, dodajmy, jest dla Marcela nieodłączna od życia przenikniętego tym, co święte, i od wiary w Boga osobowego.

To zorientowanie na religię nie miało źródeł w wychowaniu domowym Marcela, które było agnostyczno-purytańskie, lecz raczej w pewnych wydarzeniach biograficznych (wczesna śmierć matki i poczucie samotności dziecka, pomimo dobrych stosunków z ciotką, która zajęła miejsce matki), a także w przeżyciach artystycznych. Marcel — późniejszy dramaturg - wcześnie usiłował zapełniać swoją samotność różnymi wyobrażanymi partnerami dialogów, a przede wszystkim kochał muzykę; to poprzez nią (głównie J. S. Bacha) wyłania się dla niego świat niewidzialny, który adresuje się "równocześnie do mojego serca i mojego umysłu”,

1 G. M a r cel, En chemin, vers quel éveil?, Paris 1971, s. 71.

2 Tenże, Pour une sagesse tragique, Paris 1968, s. 288 n.

3 Tenże, La dignité humaine, Paris 1964, s. 39, 44; tenże, Vers une ontologie concrète, [w:] Encyclopédie française, vol. 19, Paris, 19. 14. 3. Por.: Entreitiens autour de Gabriel Marcel, Neuchâtel 1976, s. 22 n. 
i który - jak sam to stwierdza - stoi u podstaw owej pewności religijnej, o jakiej była mowa. Nie znaczy to oczywiście, by religijność Marcela przybierała od początku jakiś kształt konfesyjny. Marcel przyjął chrzest w kościele katolickim dopiero w 1929 roku w wyniku świadomej i dojrzałej decyzji, którą można śmiało określić jako nawrócenie, czyli powrót do tego, co było u Marcela ukryte, lecz obecne od wczesnych lat.

Obecność sfery religijnej nie oznacza zresztą, że zainteresowania Marcela są skierowane wyłącznie w jej stronę. Na Sorbonie, na wydziale filozoficznym, na który wstępuje w 1906 r., styka się z potężnym frontem idealizmu, a więc przede wszystkim z Kantem, Fichtem, Heglem oraz Brunschvicgiem. Od r. 1908 słucha Bergsona w College de France. Ostatnie lata studiów na Sorbonie to wpływ lektur, przede wszystkim Schellinga, ale także neoheglisty Bradleya, poprzez którego styka się z angielskim idealizmem. Dopiero w latach 1913-14 zapoznaje się z filozofią Royce'a, oraz z dziełem Hockinga The Meaning of God in Human Experience, co skierowuje go ku ,spirytualistycznemu i mistycznemu realizmowi" ${ }^{4}$. Poprzez wszystkie te i inne wpływy przebija decydujące oddziaływanie Platona oraz - wielkiej muzyki ${ }^{5}$. To spotkanie $\mathrm{z}$ wielką filozofią i kulturą $\mathrm{w}$ ogóle ${ }^{6}$ nie mogło nie tchnąć w Marcela ducha uniwersalizmu w najszlachetniejszym sensie, co przejawia się przede wszystkim w rozległości jego zainteresowań filozoficznych. Marcel jest od początku c a ły m filozofem, nakierowany jest na całokształt problematyki filozoficznej. Pietro Prini w swojej znakomitej książce o filozofii Marcela: Gabriel Marcel e la metodologia dell'inverificabile (Roma 1968), za trzy główne motywy filozofii Marcela uważa: (1) obronę człowieka konkretnego przeciwko pretensjom scientyzmu do reprezentowania poznania jako takiego (co Prini wiąże z wpływami Bradleya i Bergsona); (2) afirmację egzystencjalną świata, utożsamianą z konkretnym odczuwaniem „mojego ciała” (w przedłużeniu tradycji sensualizmu francuskiego); (3) doktrynę ,ttajemnicy ontologicznej” i partycypacji w Bycie, sięgającą korzeniami św. Augustyna, Pascala i Berulle'a? Wyliczenie to, bardzo trafne, nie jest $\mathrm{z}$ pewnością jedynym możliwym, ale w każdym razie obrazuje ono zakres zainteresowań filozoficznych Marcela.

Gdyby pokusić się o poszukanie nie tyle intuicji centralnej, ile głównej filozoficznej troski Marcela, to byłoby nią zapewne zbudowanie fi-

${ }^{4}$ L. A. Blain, The Notion of Proof for Gods Existence in Early Writings of Gabriel Marcel, Louvain 1959 (rozprawa daktorska - maszynopis); G. M a r ce 1, Vers une ontologie concrète, jw., 19. 14. 2-4.

5 Tenże, Vers une ontologie concrète, jw., 19. 14. 3.

6 Na Marcela miało także wpływ dzieło Prousta (tamże) oraz malarstwo Giotta (B 1 a i n, jw.).

7 Dzieło to znane mi jest tylko we francuskim tłumaczeniu: P. Prini, Gabriel Marcel et la méthodologie de l'invérifiable, Paris 1953, s. 11-13. 
lozofii integralnego człowieka, ,z ciałem i z duszą", to znaczy k o n k re tn e go, wcielonego, wolnego, zarazem myślącego, czującego i pragnącego, otwartego na osobowy Absolut, który jest pełnią bycia i dobra i który może człowiekowi przynieść zbawienie. Marcel oczywiście nie od począt$\mathrm{ku}$ zdaje sobie sprawę z całokształtu tego ogromnego zagadnienia, nie od razu rysuje się przed nim zarówno cały ten program, jak i metoda jego urzeczywistnienia. Można nawet powiedzieć, że nigdy go sobie w pełni nie uświadomił, a tym bardziej nie wypowiedział - nie był to filozof programów, lecz zapytywania, uważnego nasłuchiwania i nigdy nie zamkniętej, lojalnej wobec naszej skończoności i dziejowości filozoficznej wędrówki. A jednak od początku widać podstawowe dla Marcela pytania i kierunek odpowiedzi. Jest to pytanie o możliwość filozofii ludzkiego konkretu w obliczu Boga oraz przekonanie, że filozofia ta musi być w y d a r t a idealistycznemu racjonalizmowi oraz scjentyzmowi.

Droga Marcela do własnej dojrzałości jest jednak daleka, choć jej zalążki widać już we wczesnych jego pismach, — to, że droga filozofa jest jedynie stopniowym ujawnianiem pierwotnej jej intuicji i pierwotnych „założeń”, wiadomo co najmniej od czasów Bergsona i Diltheya. Przede wszystkim widać we wczesnych pismach z jednej strony, że motorem myśli Marcela jest „uczynienie zrozumiałym porządku afirmacji religijnej”, z drugiej - że troska ta idzie w parze z poczuciem konieczności zbadania podstaw poznania w ogóle i zarysowania nowej koncepcji świadomości, czy raczej „myślenia w ogóle” (niewłaściwość tego sformułowania, a zarazem paradoksalność przedsięwzięcia Marcela widać zresztą niemal od początku jego filozofowania).

Zadaniem naszym $\mathrm{w}$ tym artykule będzie prześledzenie poglądów epistemologicznych Marcela we wczesnych jego pismach w perspektywie jego myśli religijnej. Perspektywa ta nie tylko nie jest narzucona arbitralnie, lecz nawet filozofia Marcela wręcz się jej domaga. Myślenie religijne nie tylko jest ,subiektywnie" motorem tej filozofii, ale także — „obiektywnie", stanowi zwieńczenie wszystkich jej warstw. W artykule tym nie poświęcamy jednak uwagi samemu temu myśleniu, lecz jego podstawom epistemologicznym, w stopniu jednakże, w jakim przygotowują one teorię partycypacji i teorię wiary. Przedmiotem naszych analiz bęclą wyłącznie Fragmenty filozoficzne z lat 1909-1914 oraz I część Dziennika metafizycznego $\mathrm{z}$ lat $1914-1923^{8}$.

8 Oba tytuły wymienionych dzieł G. Marcela cytuję dalej skrótowo w tekście i przypisach: FPh. (Fragments philosophiques 1909-1914, introduction par L. A. B la in, Paris-Louvain 1961), JM. (Journal métaphysiques, Paris 1927). 


\section{KRYTYKA RACJONALIZMU}

Najwybitniejszy znawca pism wczesnych Marcela i wydawca Fragmentów filozoficznych 1909-1914 Lionel Blain wyróżnia cztery etapy w rozwoju poglądów Marcela na zagadnienia religii we wczesnym okresie:

1) 1909-1910 - pozycja wyjściowa: reakcja przeciw intelektualizmowi, brak decyzji co do dalszego ciągu.

2) 1910-1911 — odkrycie teorii partycypacji, pierwsze zarysy teorii wiary.

3) 1912-1913 - psychologia niepoznawalnego podmiotu, będąca w sercu wiary, teoria wiary, problem stosunku wiary i poznania historycznego.

4) 1913-1914 - szczyt tego okresu: synteza koncepcji na temat wiary ${ }^{9}$.

Nie będziemy tutaj śledzić w szczegółach ani wszystkich przemian dokonujących się w tym okresie w myśli Marcela, ani - jak już wiemy - omawiać poglądów dotyczących religii, lecz jedynie poglądy odnoszące się do poznania o ile przygotowują one teorię wiary i Boga. Zanim jednak przejdziemy do analizy okresu czwartego, najdojrzalszego, musimy możliwie precyzyjnie określić rodzaj myśli, której Marcel od początku się przeciwstawia, albo której niewystarczalność dostrzega, oraz opisać główne momenty jego krytyki; centralnym jej punktem jest krytyka wiedzy absolutnej, tak jak ją Marcel rozumiał. Dopiero poprzez konfrontację $\mathrm{z}$ tą myślą wykrystalizowują się zręby własnej filozofii Marcela, jego „epistemologii” i „ontologii”, które z kolei stanowią podstawę dla jego koncepcji Boga i wiary.

\section{Główni przeciwnicy}

Myśl filozoficzna Marcela została puszczona w ruch przez konfrontację $\mathrm{z}$ racjonalistycznym idealizmem oraz scjentyzmem, dla których jak twierdzi Marcel - orzechem nie do ugryzienia jest to, co skończone, przypadkowe, konkretne, indywidualne jako takie. „Swiat jest do pomyślenia tylko w postaci konieczności racjonalnej; z drugiej strony jest poznawalny jedynie przez doświadczenie, które nieuchronnie zostawia ogromnie wiele miejsca dla przypadkowości. I przez to problem przypadkowości nabiera nowego aspektu. Przypadkowość, chociaż nie możemy powiedzieć, że jest u korzenia rzeczy, jest wyrazem tego, co w rzeczywistości indywidualne; jest najczystszym przejawem tego istotnego faktu,

${ }^{9}$ L. A. Blain, The Notion... 
którego metafizyka nie zdołała dotychczas, jak mi się zdaje, wyjaśnić, mianowicie doświadczenia in d y w id u a ln e go właśnie. Jest tu problem, którego Kant, nawet jeśli go postawił, w każdym razie nie rozwiązał. Przejść od uniwersalności rozumu do doświadczenia indywidualnego - oto dzieło najtrudniejsze i najbardziej niebezpieczne" (FPh. s. 19).

Celem, który Marcel od początku atakuje, nie jest zatem bynajmniej transcendentalna koncepcja myślenia, której twórcą jest Kant; jest to wspólny punkt wyjścia zarówno Marcela, jak i głównych przeciwników, których zwalcza. Co więcej, jeśli za najistotniejszą dla tej koncepcji uznać nierozłączność „poznawania” (czy szerzej - myślenia) z ,tym co poznawane” (czy myślane), najogólniej rozumianego „podmiotu” z najogólniej rozumianym ,przedmiotem”, to Marcel będzie zawsze bronić tej nierozłączności w imię uczciwości myślenia i wierności doświadczeniu. Właśnie dlatego głównym przedmiotem polemiki Marcela nie jest filozofia Kanta (którego będzie zresztą później surowo krytykował), lecz idealizm absolutny $\mathrm{w}$ wydaniu przede wszystkim Hegla oraz racjonalizm scjentystyczny głównie $\mathrm{w}$ wydaniu Brunschvicga. O ile pierwszym z nich rządzi to, co można by nazwać ,zasadą immanencji”, o tyle drugim rządzi „zasada obiektywności” ${ }^{10}$. Obiema tymi zasadami włada r a c j o n a li z m, który przejawia się zresztą także w pewnego typu metafizyce przedkrytycznej i dlatego ostrze krytyki Marcela zwraca się również przeciwko niej. Zasadniczym błędem racjonalizmu w obu wymienionych postaciach jest zapoznanie zarówno indywidualnej skończoności, jak i transcendentnego Boga.

Dla idealizmu absolutnego w wydaniu np. Hegla (takim, jak go widzi Marcel) całokształt rzeczywistości utożsamia się z myślą w ruchu dialektycznym, która jest w ten sposób absolutem; nic się jej nie przeciwstawia, nic nie jest w stosunku do niej transcendentne, a ona jest wszystkiemu immanentna. Dla koncepcji tej nie ma w gruncie rzeczy niczego poza wieczną subiektywnością, gdyż tylko myśl jest prawdą skończoności, a tylko w swej prawdzie to co skończone w ogóle j e s t. Jeśli jednak tak, to myśl „wchłaniając” skończoność jako jej prawda utożsamia się z nią zarazem. W ten sposób zostaje przekreślona za jednym zamachem zarówno możliwość transcendencji Boga, jak i odrębność skończonych rzeczy, a w szczególności skończonego ludzkiego d ośw i a d c z e ni a. Myśl jako jedyny absolut, a więc „Bóg”, jest w gruncie rzeczy sumą skończoności, natomiast my sami jako skończeni wraz z naszym indywidualnym doświadczeniem zostajemy umieszczeni obok innych skończonych rzeczy i wchłonięci przez ów absolut; ta wizja monistyczna nie różni w sposób istotny Hegla od Spinozy. Ponadto, skoro absolutna prawda jest jedyną

10 P. Prini, jw., s. 19. 
rzeczywistością, to to, co skończone, nieuchronnie staje się pozorem, iluzją — to jest jeden z elementów Marcelowskiej krytyki „wiedzy absolutnej", o której będzie zaraz mowa ${ }^{11}$. Jeśli jednak nie przyjmie się tej konsekwencji, trzeba wówczas w y d e d u k o w a ć to, co skończone, z tego, co nieskończone. Próbował tego dokonać Leibniz (zakładając, że gdybyśmy dokonali nieskończonej analizy rzeczywistości, wiedzielibyśmy, jak z nieskończoności wynika skończoność - ale właśnie nie możemy tego dokonać, a zatem...), próbował Fichte (wprowadzając w trzech etapach 'ja' skończone z 'ja' absolutnego - ale dlaczego skończone 'ja' miałoby być takie właśnie, jakie jest? ${ }^{12}$ — jednakże na próżno. „Nie ma przejścia od nieskończoności do skończoności, widział to doskonale Brunschvicg po tylu innych. Z punktu widzenia nieskończoności, to co skończone jest negowane jako istniejące; z punktu widzenia skończoności, nieskończoność jest negowana jako poznawalna" (FPh. s. 19).

Może więc wyjściem $\mathrm{z}$ tego dylematu byłoby przyjęcie scjentyzmu w wydaniu Brunschvicga? Leon Brunschvicg - trzeba tu przypomnieć, jako że jest on filozofem mało u nas znanym - odrzucał myśl o wynikaniu kategorii, w które ujmujemy rzeczywistość, z dialektycznego procesu, niezależnego od poszczególnych nauk. Odrzucał zarówno idealistyczny racjonalizm, jak i empiryzm na rzecz scjentyzmu; trzeba respektować zarówno fakty, jak i wielość umysłów. Jednakże prawdą dla Brunschvicga jest jedynie to, co może być s p r a w d z o n e przez wiele umysłów; wiedza polega na tym, co wspólne wszystkim umysłom i co może być przez nie kontrolowane. Tym zaś, co może być wspólne wszystkim umysłom, jest oczywiście coś, co ma być zbadane ,obiektywnie” pr zedmi ot jako korelat nauki. Intelekt może jedynie prześledzić fazy myśli naukowej, przemyśleć je i sprawdzić. Filozof ma jedynie rozumieć i kontrolować to, co robi nauka ${ }^{13}$. Marcel w pierwszej fazie swej filozofii akceptuje utożsamianie przez Brunschvicga prawdy ze sprawdzalnością. Krytykuje go natomiast dwojako:

1) Nie można utożsamiać rzeczywistości z prawami naukowymi, nawet jeśli są one odniesione do - naukowo rozumianego - doświadczenia, gdyż nauka nie jest niczym innym, jak warunkiem możliwości rozumienia rzeczywistości. Warunek ten zaś zakłada „myśl uniwersalną”, konstytuującą $\mathrm{w}$ kontakcie $\mathrm{z}$ doświadczeniem te prawa, a więc te prawa przekraczającą, transcendującą. Rzeczywistość w równym stopniu nie pokrywa się z prawami naukowymi, co z triadami dialektyki heglowskiej.

11 Por. FPh. s. $31-33$.

12 Por. J.-P. B a got, Connaissance et amour. Essai sur la philosophie de Gabriel Marcel, Paris 1958.

13 L. A. Bla ine, The Notion... 
„Wiedza wykończona jest zawsze abstrakcją; może pojmować siebie jedynie jako ideał, odniesiony do myśli działającej, żywej” (FPh. s. 21).

2) Nie można utożsamiać podmiotu jako takiego $\mathrm{z}$ podmiotem wiedzy, ani uniwersalności z uniwersalnością wiedzy. Podmiot jest czymś więcej niż podmiotem wiedzy, a wspólnota między ludźmi nie opiera się bynajmniej na porozumieniu na temat wiedzy. Jak napisze szereg lat później: „Brunschvicg w fakcie, że mogę porozumieć się np. z moim sąsiadem na temat kalkulacji i rachunków, widzi korzeń, a nawet gwarancję duchowej wspólnoty. Jestem $\mathrm{w}$ tym punkcie $\mathrm{w}$ radykalnej $\mathrm{z}$ nim niezgodzie”. Wspólnota ludzka to raczej „wspólnota związana z doświadczeniem słabości" ${ }^{14}$.

\section{Krytyka wiedzy absolutnej}

W tzw. Rękopisie XII z lat 1910-1911 Marcel rozprawia się z ideą wiedzy absolutnej, przypisaną niewątpliwie przede wszystkim myśli Hegla, choć traktowaną niezależnie od konkretnej zawartości jego poglądów. Dla Marcela problem wiedzy absolutnej jest nade wszystko problemem relacji nieskończoności do skończoności, a więc - Boga i świata ${ }^{15}$.

Marcel udawadnia, że wszystkie rozwiązania intelektualistyczne tej relacji prowadzą do sprzeczności:

1) Nieskończoność wiedzy absolutnej z założenia nie jest jedynie nigdy się nie kończącą sumą poznań skończonych, a więc pewnym pojęciem n e ga ty w n m. Jest pojęciem czegoś absolutnego, co jako takie musi być pozytywne. Otóż absolut jako taki nie może być złożony, musi być prosty, nie może być więc sumą niczego. Jeśli równocześnie absolut jest tu rozumiany jako to, co obejmuje wszystko i poza czym nie ma niczego, co zatem po prostu jest wszystkim, to jedno $\mathrm{z}$ dwojga: albo absolut jest wszystkim i w ten sposób wyklucza to, co skończone, albo odwrotnie - jest tylko to, co skończone, ale $\mathrm{w}$ takim razie nie ma nieskończoności.

2) Wiedza absolutna - nieskończoność - jest równocześnie i jedynie p r a d ą skończoności, co znaczy, że ma ona do tej skończoności konieczne odniesienie: (a) pozyty wi e: czerpie z niej wszelkie określenia - poza sumą poznań określony ch, a więc skończonych wiedza absolutna byłaby pusta i niezrozumiała; (b) ne gaty w nie: skoro jednak prawda skończoności jest w nieskończoności, to skończoność jako taka jest nie-prawdą, błędem, złudzeniem. W jaki jednak sposób złudzenie może być wintegrowane w wiedzę absolutną, nie przestając być sobą? Jest sobą przecież tylko jako to, co skończone i ograniczone.

14 Dyskusja z Brunschvicgiem w L'Union pour la Vérité w dniu 28 IV 1928 przytoczona w Du refus d̀ l'invocation (s. 10-15) Marcela. 
Jak można by zatem w ogóle rozumieć wiedzę absolutną i przejąć to, co w niej ewentualnie prawdziwe? Można ją rozumieć jedynie jako „,idealną koncentrację, jako doskonałą wizję tego, co w skończoności wydaje się irracjonalnie rozproszone" (FPh. s. 36). Według Marcela afirmacja takiego absolutu rozumności jest nawet z konieczności zawarta w każdym akcie myśli jako wymóg pełnej prawdy. Ale może to znaczyć albo: (a) ideał dla myśli skończonej - ale musiałby to być z konieczności ideał niezrealizowany ${ }^{16}$, albo (b) transcendentną $\mathrm{w}$ stosunku do wszelkich świadomości skończonych, wieczną, absolutną, boską myśl ${ }^{17}$. Jednakże w perspektywie idealizmu racjonalistycznego także ta wieczna świadomość nie jest do pomyślenia, gdyż albo traktuje się ją jako realny absolut, żyjący w wieczności, a więc pon a d czasem - ale wówczas odcina się ją od skończonych świadomości, których niezbywalnym piętnem jest czasowość, i czyni czymś całkowicie niepoznawalnym (,rzeczą samą w sobie") i w istocie niezrozumiałym, albo wpada się we wszystkie trudności, wynikające $\mathrm{z}$ relacji nieskończoność-skończoność. W obu tych postaciach wiedza absolutna jawi się więc jako niemożliwa do zaakceptowania.

W ten sposób jednak niemożliwe jest utożsamienie tego, co realne i tego, co w pelni zrozumiałe. Skoro bowiem absolutna wiedza, a więc i prawda jest niemożliwa jako absolutna rzeczywistość, to to, co realne, nie może być w pełni zrozumiałe (,prawdziwe”), zaś pełna zrozumiałość może być jedynie ,ideą regulatywną”, a zatem czymś idealnym, a nie realnym. Wszystkie trudności pochodzą stąd, że „hipositazujemy” wymóg myśli i sądzimy, że możemy wyizolować i rozpatrywać samą w sobie tak otrzymaną pseudo-rzeczywistość ${ }^{18}$. „Filozofie wiedzy absolutnej są, jak się zdaje, ofiarami tego samego złudzenia, co realizmy naiwne. Sądzą, że mogą przeciąć więź, która łączy przedmiot (tutaj: wiedzę absolutną) $\mathrm{z}$ podmiotem i traktować przedmiot jako byt, nie spostrzegając, że byt ten zawdzięcza swoją rzeczywistość partycypacji w podmiocie" (FPh. s. 44). Wiedza absolutna jest zawsze jedynie ideałem, wiedza rzeczywista jest zawsze skończona - oto konkluzja krytyki Marcela.

\section{Zarys teorii partycypacji}

Dla Marcela jest jednak oczywiste, że myśl i rzeczywistość są nierozerwalne. Nazywa to raz ,immanencją bycia (de l'être) w myśli” (FPh. omówił.

15 W streszozeniu tej krytyki idę za Blainem (The Notion...), który ją doskonale

16 Pol. FPh. s. 39.

17 Por. tamże, s. 43.

18 Por. tamże, s. $44 \mathrm{n}$. 
s. 46), raz „syntetyczną tożsamością bycia i myśli”, w istocie jednak rozumie pod tym relację całkiem specyficzną, dla której znajduje określenie ,partycypacja”. Punktem wyjścia teorii partycypacji jest podwójne przekonanie:

1) Nie można negować odniesienia myśli do czegoś innego, niż ona sama i twierdzić, ani że nic (poza myślą) nie jest realne (byłoby to intelektualne samobójstwo), ani że to, co realne, jest niedostępne dla umysłu (zakładałoby to $\mathrm{m}$. in. tożsamość rzeczywistości i rozumności $=$ pojęcie wiedzy absolutnej samej w sobie).

2) Nie można przejść do rzeczywistości od systemu wiedzy (absolutnej), gdyż w ramach tej wiedzy wszystko jest rzeczywiste jedynie poprzez odniesienie do całego systemu, który naprawdę nie jest nigdy pełny i jest - jak wiemy - sam w sobie sprzeczny.

Skoro tak, to trzeba przyjąc swoistą równorzędność myśli i bycia oraz ich wzajemną immanencję i transcendencję: „Trzeba więc, by byt jako byt był immanentny umysłowi, a z drugiej strony transcendentny względem wszelkiej «idei» bytu, która staje się naszą «wiedzą» (FPh. s. 63 n.).

Punkt zaczepu dla swej teorii znajduje Marcel w "sprzeczności” charakteryzującej wszelką wiedzę, a mianowicie, że u podstaw wszelkiego poznania jest coś, co z istoty swej wymyka się wszelkiemu poznaniu sam akt poznania, ,czysty podmiot” (FPh. S. 51). Jest on niepoznawalny $z$ is to ty, a nie przypadkowo, jak coś co powinno dać się poznać, a tylko nie może ze względów faktycznych. Czy nie jest on w takim razie pustą abstrakcją, czymś w rodzaju rzeczy samej w sobie? Marcel twierdzi, że staje się on takim tylko wtedy, gdy sam siebie uprzedmiotawia, gdy próbuje siebie ,zobaczyć" przed sobą jako przedmiot ${ }^{19}$. Czy jest on tożsamy z podmiotem wiedzy? I tak, i nie. W pewnym zasadniczym sensie nie, gdyż wiedza, jako relacja podmiotu i przedmiotu, jest już dla „podmiotu czystego"; to raczej podmiot czysty "godzi się" lub nie na swoją tożsamość z podmiotem wiedzy. Wiedza nie zawiera się również w podmiocie czystym potencjalnie, wówczas bowiem byłby on jedynie utajoną wiedzą absolutną. A jednak podmiot czysty jest „odniesiony” do bycia, jest bowiem podmiotem myśli, która jest niczym bez odniesienia do bycia, przy czym - jest to od początku przekonanie Marcela bycie jest, jeśli tak można powiedzieć, w żywotnym związku z myślą. Trzeba w takim razie powiedzieć, że myśl „partycypuje” w byciu, ale zarazem zabronić jakiegokolwiek ,,przedstawienia” sobie tej relacji. Znaczyłoby to bowiem relację tę us t a n ow i ć jako przedmiot myśli, a zatem zniweczyć. Jeśli jednak tak, to być może pojęcie partycypacji jest sprzeczne? Nie wiemy tego, bowiem sprzeczność pojawia się tylko po-

19 Por. tamże, s. 53. 
przez myśl refleksyjną, uprzedmiotawiającą. Partycypacja zatem wyklucza "refleksję" nad nią, ale ni e wszelkie jej myślenie. Jawi się ona jako „górna granica refleiksji, na obrzeżach idealizmu”.

Partycypacja nie jest tożsama z „egzystencją”, która — jak to dalej zobaczymy - jest przez wczesnego Marcela utożsamiana z czystą nieokreślonością relatywną względem określeń przedmiotowych, to znaczy z czymś poniżej progu refleksji. Partycypacja może być pomyślana jedynie jako wolna abdykacja myśli z wszelkiej uprzedmiotawiającej ,re-fleksji", jako jej swoista rezygnacja.

Ten akt abdykacji nazywa teraz Marcel w i a $\mathrm{r}$ ą. Czego ona dotyczy? „Trzeba zauważyć, że wiara nie dotyczy ani bycia, ani nawet partycypacji w ogóle [...], lecz partycypacji podmiotu jako niepoznawaln e g o w byciu" (FPh. s. 64). Ale wiara ta dotyczy zarazem Boga: ,[...] można powiedzieć, że wiara dotyczy istnienia Boga. Ale jest oczywiste, że wyrażenie to nie może być wzięte dosłownie; Bóg nie istnieje, jest nieskończenie ponad istnieniem, ponieważ jest ponad wszelką prawdą i może być ujęty przez wiarę jedynie w akcie, który łączy Go intymnie z myślą. Czy możemy teraz przeniknąc głębiej w naturę tej partycypacji? Jawi się ona w sposób istotny jako tajemnica, to znaczy jako wymykająca się wszelkiej metodzie analizy, która przekształcałaby ją w przedmiot" (FPh. s. 65).

Dlaczego wiara? Na to pytanie odpowiada teoria wiary zawarta $\mathrm{w}$ pełni w Dzienniku metafizycznym, której w tym artykule nie rozwijamy. Jej podstawą natomiast jest wgląd w szczególny sposób, w jaki podmiot jawi się sam sobie. Wiara zakłada mianowicie u swych podstaw ujęcie podmiotu przez siebie samego jako niepoznawalnego. Jak to jest możliwe? Przez akt, w którym podmiot myśli „odnosi się” do podmiotu wiedzy i jakoś go rozumie, rozpoznaje siebie zarówno jako to ż a m e g o z podmiotem wiedzy, jak i przekracza ją c e go go. W akcie tym podmiot doświadcza swojej transcendencji i w ten sposób afirmuje swoją wolność. „Przez akt transcendencji, który przekracza wszelką refleksję $\mathrm{i}$ jest bezpośredni $\mathrm{w}$ tym sensie, że jest transcendentny względem wszelkiej mediacji myśli, myśl afirmuje, że jest tożsamy z podmiotem [wiedzy]; akt ten jest intuicją intelektualną [...] Intuicja intelektualna jest w sposób oczywisty wstępnym warunkiem wiary i inauguruje nowy typ zrozumiałości" (FPh. s. 67). Ujęcie siebie jako wolności jest niezbędnym warunkiem ujęcia mojego odniesienia od Boga.

Teoria partycypacji i wiary z Fragmentów filozoficznych znajdzie swoje rozwinięcie i przedłużenie w teorii wiary z I części Dziennika metafizycznego, której epistemologiczne podstawy obecnie zarysujemy. 


\section{KONCEPCJA RÓŻNYCH POZIOMÓW ZROZUMIA£OSCI}

Pojęcie istnienia (egzystencji) we wczesnej filozofii Marcela

Dojrzałe poglądy epistemologiczne Marcela we wczesnym okresie, wykrystalizowane $\mathrm{w}$ nim $\mathrm{w}$ polemice $\mathrm{z}$ racjonalizmem, a wyznaczające niezastąpione miejsce dla wiary w Boga, zawierają koncepcję wielości poziomów ,inteligibilności”.

U spodu hierarchii, na jej najniższym poziomie znajduje się to, co Marcel nazywa istnieniem czy „egzystencją". Istnienie jest zasadniczo tym, co dane dla bezpośredniej świadomości. Ale może to oznaczać różne rzeczy. (1) „Jest plan, na którym nie tylko świat nie ma sensu, ale na którym jest nawet sprzecznością zapytywać, czy ma ten sens; jest to plan bezpośredniego istnienia, w sposób konieczny plan tego, co przypadkowe [...]. Z punktu widzenia bezpośredniej świadomości nic nie może być wyjaśnione, ani nawet po prostu zrozumiane [...] to, co bezpośrednie, jest zaprzeczeniem zasady zrozumiałości" (JM. s. 3). Dla Marcela zatem istnienie to najpierw poziom nie objęty sensem i dlatego niezrozumiały. Ale skąd w takim razie o tym poziomie w ogóle wiemy? Stąd, że myśl „skądeś wychodzi”, to znaczy może być określona jako przekraczanie danych tego, co „faktyczne”.

A zatem (2) można określić istnienie jako „czystą faktyczność” i w tym sensie czysty punkt wyjścia myśli - dlatego istnienia nigdy nie można u dow odnić. „Istnienie nie może więc w żadnym wypadku być uważane jako demonstrandum, jako punkt dojścia" (JM. s. 32). Nie można go ani udowodnić, ani wyprowadzić $\mathrm{z}$ myśli. Będzie to miało zasadnicze znaczenie dla zagadnienia istnienia Boga.

To, co dane, punkt wyjścia - to percepcja zmysłowa. Dlatego (3) można bliżej scharakteryzować istnienie jako to, co jawi się $w$ naszej percepcji, a więc $w$ relacji do naszego ciała. Ta bezpośrednia, percypująca świadomość odznacza się z kolei wymiarem czasowym, to znaczy jest czystą aktualnością, teraźniejszością. I w stosunku do tej aktualności musi być określone wszystko, co może być uznane za istniejące. „Gdy mówię: Cezar istniał - a biorę przykład z przeszłości, ponieważ tu właśnie definicja wydaje się najbardziej wątpliwa - chcę nie tylko powiedzieć, że Cezar mógł zostać przeze mnie zauważony; chcę powiedzieć, że między istnieniem Cezara a swoim stanem świadomości, moim aktualnym uświadomieniem zachodzi seria (nieskończenie skomplikowana) stosunków czasowych, która może być obiektywnie określona. Mój aktualny stan świadomości, związany z położeniem zorganizowanego ciała, które ów stan świadomości wyraża, jest punktem odniesienia, w 
stosunku do którego porządkuje się nieskończona wielorakość tego, co może być myślane przeze mnie jako istniejące. Wszelkie istnienie może być odniesione do tego punktu i tylko przez abstrakcję może być myślane poza wszelkim stosunkiem do niego" (JM. s. 15). Krótko mówiąc: istnieje (egzystuje) tylko to, co mogłoby być przeze mnie spostrzeżone w czasie i przestrzeni. Jest oczywiste, że w świetle takiej koncepcji istnienia Marcel będzie go musiał odmówić Bogu.

(4) „Cezar istniał”, ,to oto krzesło istnieje” — to s ą dy e g z y s t e nc ja ln e. Czy sądy te wyjaśniają jakoś bliżej, czym jest istnienie? Otóż zarówno je wyjaśniają, jak zaciemniają. Zaciemniają, albowiem istnienie jest bezpośredniością, gdy tymczasem sądy egzystencjalne wprowadzają dualizm między świadomością a tym, czego świadomość dotyczy, a także między „materią" tego, co dane, a „formą" istnienia. Tylko więc wówczas, gdy świadomość zaneguje ów dualizm, który od niej pochodzi, może utworzyć sobie pojęcie pierwotnej bezpośredniości istnienia, którą z tej perspektywy nazywa Marcel „doświ a dczeniem granicznym". „Doświadczenie graniczne może być myślane jedynie przez akt refleksji dotyczący dualizmu sądu egzystencjalnego i tego, czego ów sąd dotyczy. To doświadczenie graniczne o tyle, o ile podmiot refleksji chce $\mathrm{z}$ niego wycisnąć zawartość obiektywną, redukuje się do kontaktu między ciałem, związanym ze świadomością percypującą, a pewną daną zewnętrzną. Myśl reflektująca ustanawia więc sąd egzystencjalny jako będący transpozycją w porządku intelektualnym [...] doświadczenia granicznego" (JM. S. 25 n.). Transpozycja ta, dokonująca się poprzez intelekt, przekłada na stosunki przestrzenne to, co samo w sobie jest czystą bezpośredniością.

Cała ta omówiona koncepcja istnienia, bez wątpienia związana $\mathrm{z}$ epistemologią idealizmu Kanta i jego następców, wypracowuje jednak ważne pojęcie „doświadczenia granicznego”, które Marcel później w pewnej mierze podejmie i odnowi. W tej jednak wersji jest oczywiste, że wszelkie ewentualne określenia Boga muszą Go pozbawiać momentu egzystencjalnego.

\section{Myśl racjonalna}

Następny poziom, który Marcel uwzględnia - to poziom myśli racjonalnej. Myśl racjonalna charakteryzuje się tym, że wprowadza nieredukowalne dualiz m y:

1. Pierwszy i zasadniczy dualizm, na który myśl napotyka, to dualizm mnie jako myśli i mnie jako empirycznego; jako myśl rozumiem jedynie to, co ogólne, podczas gdy jestem zarazem „empiryczny” i indywidualny, jestem więc wewnętrznie rozdarty, „Schizofreniczny”. Dla myśli racjonalnej dualizm ten, który ustanawia ona sama, jest niemożliwy do zrozu- 
mienia, a równocześnie jawi się on jako katastrofalny z punktu widzenia praktycznego. „Gdyby dualizm ten był naprawdę afirmowany, rujnowałby każde działanie, albo raczej czyniłby je niemożliwym. Mogę działać tyljko o tyle, o ile neguję ten dualizm, działanie jest samą tą negacją" (JM. s. 6). Mogę próbować myśleć między obu aspektami mojego ja jakiś związek, ale byłby on jedynie jakimś postulatem typu „,rzeczy samej w sobie”, w postaci np. ,podświadomości”, która nie może nigdy naprawdę być dana, a jedynie pomyślana (tak, jak idea w sensie kantowskim).

2. Inny dualizm myśli racjonalnej - to dualizm czasu i tego, co ponadczasowe. Działanie dokonuje się w czasie. A myślenie? Ono też dzieje się $\mathrm{w}$ czasie, ale zarazem ma do czynienia z pojęciami czy ideami, które roszczą sobie pretensje do ponadczasowości. Wówczas myślenie racjonalne zmierza nieuchronnie do jakiegoś redukcjonizmu: albo więc sprowadza to, co bezczasowe do czasowości (empirycznej), albo odwrotnie - wsysa to, co empiryczne $\mathrm{w}$ monizm idealistyczny ${ }^{20}$.

3. Oba te dualizmy można sprowadzić do trzeciego dualizmu: pozoru i rzeczywistości. Dla konsekwentnego idealizmu wielość empiryczna zawsze będzie pozorem: ja empiryczne będzie jedynie sposobem jawienia się myśli samej w sobie, czas - sposobem, w jaki ponadczasowy absolut, który stanowi jedyną prawdę rzeczywistości, dochodzi do tej jedynej prawdy o sobie itp. ${ }^{21}$ Marcel pisze, że żadne próby kompromisowych rozwiązań nie są możliwe do utrzymania: ani monizm idealistyczny typu Bradleya, który mówi o jakiejś przemianie pozorów w łonie rzeczywistości, ani dualizm ontologiczny Spira, który z jednej strony stwierdza odrębność ontologiczną absolutnej „normy”, z drugiej przecież strony tylko normie przyznaje rzeczywistość.

Ogólnie mówiąc, na dualizmy nie jest w stanie zaradzić ani empiryzm, ani idealizm. Empiryzm przekreśla myśl, która jest jego własnym warunkiem możliwości, przez co jest on intelektualnym samobójstwem; idealizm natomiast lekceważy pluralizm rzeczywistości, coś, co Marcel określa kategorią ,także” (l'aussi), o której pisze tak: „Istnieje plan myśli, który jest planem «także», cokolwiek by się robiło, żeby go zanegować. Zagadnienie polega na tym, by wiedzieć, czy zaprzeczając, że ten plan jest ostatecznym, przez to samo afirmujemy monistyczną tezę o sprowadzalności wszystkich związków zewnętrznych do stosunków wewnętrznych [to znaczy myślowych]" (JM. s. 95). Odpowiedzią na te trudności jest własna koncepcja Marcela, która rozwija się $\mathrm{w}$ dwóch kierunkach: $\mathrm{w}$ kierunku teorii związku intelektu $\mathrm{z}$ doświadczeniem oraz w kierunku teorii wiary. Pierwsza $\mathrm{z}$ nich znajdzie pewną kontynuację $\mathrm{w}$ dalszym

20 Por. JM. S. 10.

${ }^{21} \mathrm{Ch}$. Wi dmer, Gabriel Marcel et le théisme existentiel, Paris 1971, s. 27. 
rozwoju epistemologii Marcela, ale nie prowadzi wprost do teorii wiary, dlatego przedstawimy ją jedynie całkiem krótko.

Chociaż Marcel porusza się wewnątrz filozofii transcendentalnej, to jednak jego własna teoria intelektu, a szerzej — „inteligibilności” czy „zrozumiałości”, wychodzi zarówno poza Kanta, jak i poza empiryzm, a także poza Hegla. Jej nerwem jest krytyka formalizmu kantowskiego, która prowadzi również do teorii wiary. Na temat formalizmu pisze: „Formalizm [...] przedstawia ten niezwykle poważny błąd, że nie może zdać sprawy z aktu, który go umożliwia" (JM. s. 43). Umieszcza on garnitur gotowych kategorii formalnych a priori naprzeciwko bezkształtnej materii w sposób w istocie całkowicie niezrozumiały. Tymczasem naprawdę myśl jest życie m d u cha i konstytuuje się jedynie p oprze z doświadczenie i w sposób stopniowy: „Oznacza to - pisze Marcel — że koncepcja czystej myśli poprzedzającej [...] wszelkie doświadczenie, jest z pewnością psudo-ideą; jest to produkt refleksji schematycznej i złudnej" (JM. s. 75). To, co funkcjonuje jako materia dla formalizmu, a co można by nazwać ,zewnętrznością", stanowi integralną składową owego życia ducha. Pod tym względem Marcel zgodziłby się z absolutnym idealizmem. Ale wniosek, który z tego wyciąga, wyprowadza go od razu poza niego: „,W momencie, w którym zrozumieliśmy fundamentalną rolę zewnętrzności jako momentu życia duchowego, idea systemu [...] jawi się jako sprzeczna" (JM. s. 103 n.). Tego, co zewnętrzne, nie da się nigdy do końca zracjonalizować i wtłoczyć w sys te m. Życie umysłu jest najgłębiej dynamiczne i dziejowe: „Inteligibilność taka, jak ją rozumiem, jest stosunkiem dynamicznym, stosunkiem napięć przez które duch się konstytuuje, organizując swój świat; nie może on się realizować poza tym stosunkiem" (JM. s. 104).

Zrozumiałość typu racjonalnego jest na pewnym poziomie konieczna, ale nie jest to $\mathrm{z}$ pewnością etap najważniejszy i nie może sobie rościć pretensji do wyczerpania całości życia myśli; dualizmy, które ustanawia, pokazują, że intelekt nie jest w stanie dotrzeć do ich źródeł, do tego, co źródłowe. Trzeba więc odważnie przekroczyć plan myśli racjonalnej. Okaże się jednak, że koszt tej operacji jest niemały. Trzeba będzie ni mniej, ni więcej, tylko zrezygnować na pewnym etapie z pojęcia prawdy.

W jaki bowiem sposób można u s p r a w i ed li w i ć porzucenie planu myśli racjonalnej? Oczywiście tylko w ten sposób, że zbuduje się inną, szerszą teorię świadomości. Ale trzeba również dysponować odpowiednio szeroką teorią prawdy, dla której prawda w sensie racjonalnym nie jest jedyną obowiązującą. Taką teorią jednakże Marcel jeszcze nie dysponuje. 


\section{Prawda $i$ cogito}

Dla Marcela tak samo, jak np. dla Brunschvicga, prawda wiąże się najściślej ze sprawdzalnością. Nie można mówić o prawdzie tam, gdzie coś nie może być sprawdzone; sprawdzone zaś może być tylko to, co w czasie i przestrzeni, przez niezaangażowanego i doskonale wymienialnego obserwatora. Sprawdzenie jest sprawdzeniem jakiegoś przedmiotu empirycznego w stosunku do mniej lub więcej apriorycznych i ogólnych konstrukcji intelektualnych, np. jakichś praw matematycznego przyrodoznawstwa, albo na poziomie filozoficznym kategorii ontologicznych, np. przyczynowości lub substancji. Rozpoznać zatem coś jako prawdziwe, to wintegrować to w pewną zrozumiałą całość, tak że w procesie sprawdzania intelekt $\mathrm{w}$ istocie sprawdza samego siebie. Może bowiem sprawdzić tylko to, co już uczynił zrozumiałym, dzięki „włożonym” uprzednio w rzeczywistość własnym konstrukcjom. Prawda zatem to zgodność intelektu z samym sobą jako funkcją doświadczenia ${ }^{22}$.

Jeśli tak, to prawda i sprawdzalność są ściśle paralelne. Mogą być prawdy niemożliwe do sprawdzenia de facto (np. jakiś odległy fakt historyczny), ale nie może być prawd niesprawdzalnych de iure, to znaczy poza czasem i przestrzenią. Sprawdzenie to odniesienie czegoś do mojej percypującej świadomości i w ten sposób przypisanie mu lub odmówienie egzystencji, istnienia. Prawda i istnienie są ściśle korelatywne. Gdyby „istniało" coś, co byłoby poza wszelką możliwą sprawdzalnością, to byłoby ono eo ipso zarówno poza prawdą, jak i poza istnieniem. Musiałoby być w ścisłym sensie ,nieweryfikowalne”.

Czy jednak możemy o czymś takim sensownie mówić? Albo raczej: czy mamy do czegoś takiego jakikolwiek dostęp tak, aby mówienie o tym nie było czczą gadaniną? Otóż Marcel uważa, że już w samym pojęciu prawdy zawiera się odniesienie do czegoś poza nią, a zatem i ponad istnieniem. Mianowicie prawda jest prawdą jedynie $\mathrm{d} l \mathrm{l}$ a myśli, która $\mathrm{w}$ ten sposób przekracza prawdę $\mathrm{i}$ istnienie, a więc czas i przestrzeń: „W rzeczywistości prawda jest możliwa jedynie dla myśli, która sama wyzwala się z warunków czasu i przestrzeni. Prawda dotyczy tylko tego, co w czasie i przestrzeni, ale prawda jest tylko d l a myśli, która określa siebie poza czasem i przestrzenią" (JM. s. 30). Skoro tak, to myśl jest w stosunku do warunków czasowo-przestrzennych wolna, ale w ten sposób jest poza możliwym sprawdzeniem, a więc i poza prawdą: „Wolność, warunek wszelkiego sprawdzenia musi być sama myślana jako radykalnie niesprawdzalna, jako wyzwolona $\mathrm{z}$ warunków istnienia, którym musi przedmiot zadośćuczynić, by mógł być sprawdzony (określony jako praw-

22 J.-P. B a got, jw., s. 47. 
da)" (JM. s. 31). Prowadzi nas to do zupełnie nowego poziomu zrozumiałości, który musi się rządzić własnymi kryteriami, mianowicie kryteriami wartości: „Zaprowadza nas to do myślenia rzeczywistości, która określałaby się sama jako wartość (przy czym akt, który określa wartość, i ten, który określa kryterium, są korelatywne i w istocie identyczne)" ${ }^{23}$.

W ten sposób osiągamy plan a k t u myśli jako takiego, który Marcel określa jako „cogito”: „ „Myślę» nie jest daną, nie jest formą, jest aktem. Sądzę, że Descartes poszedł tu dalej niż Kant" (JM. s. 37). Jak można bliżej określić ów plan myślenia, który jest już także planem wolności? Poprzez samoustanawianie, konstytuowanie siebie samego. „Akt przez który to, co niesprawdzalne, jest myślane, w istocie go konstytuuje [...] Myśl, zastanawiając się nad ruchem, w którym konstytuują się prawdy, odkrywa konieczność myślenia tego ruchu w odniesieniu do aktywności czysto intelektualnej. Czy znaczy to, że aktywność ta jawi się jako warunek faktyczny, jako istniejąca? Jest oczywiste, że nie [...] Czysta aktywność, o której mówimy, może pojawić się jedynie dla refleksji, dotyczącej warunków możliwości prawdy [...] Akt, poprzez który myślę wolność, jest tym samym aktem, poprzez który ona się konstytuuje [...] Ten akt tworzenia, to nic innego, jak cogito. Myśl tworzy siebie myśląc siebie. Nie odnajduje siebie, lecz się konstytuuje" (JM. s. 31 n.).

Ale czy cogito jest jedynym, właściwym sposobem istnienia wolności, czy wyczerpuje jej ,potencjalności”? Cogito, rozumiane jako warunek możliwości prawdy, jest wciąż jeszcze do niej odniesione, to znaczy jest aktem „myśli w ogóle”. „W cogito 'ja' wyraża akt, przez który wolność konstytuuje się sama. Tylko, że to 'ja' jest uniwersalne, a w każdym razie znosi samo siebie w uniwersalności podmiotu myślącego. O tyle, o ile myślę, jestem uniwersalny, i jeżeli wiedza zależna jest od cogito, to właśnie dzięki tej uniwersalności, właściwej podmiotowi myślącemu" (JM. s. $40 \mathrm{n}$.). W związku z tym wolność jest $\mathrm{w}$ cogito stale zasłaniana przez formy myśli, które cogito wytwarza. A formy te ustanawiają od razu dualizm między cogito a 'ja' empirycznym, gdyż oba te pojęcia są wzajemnie korelatywne. Ustanawiając ten dualizm, cogito nie jest w stanie zdać sprawy ze wzajemnej relacji jego członów; miota się między empiryzmem a idealizmem w różnych wersjach, nie mogąc sobie z tym problemem poradzić. Empiryzm jest - powtórzmy - nie do przyjęcia, gdyż „,prawda stosunku, którą się chce tu ustalić, wymaga jako swej możliwości tego samego cogito, które chce się wintegrować w syntezę empiryczną" (JM. s. 44). Idealizm jest skazany na poszukiwanie jakiejś ,transcendentnej syntezy", która miałaby być prawdą tej relacji, będąc rów-

${ }_{23}$ G. Marcel, Wstęp do tezy o metafizycznych podstawach rozumienia religijnego (ineditum z lat 1913-1914), cytat u J.-P. Bagota (jw., s. 50) i Ch. W i dmera (jw., s. 33). 
nocześnie niemożliwą do pomyślenia. W istocie nie jest tu możliwa do ustalenia żadna prawda, ponieważ w o b u ukonstytuowanych przez cogito członach zawarty jest wszak akt myśli, który jako niemożliwy do sprawdzenia przekracza wszelką prawdę. W takim razie relacja między nimi musi być zinterpretowana jako niesprawdzalna. „Myśl musi stwierdzić [poser], że relacja 'myślę' do porządku empirycznego jest niesprawdzalna". Przez to „zostaje stwierdzona [posée] co najmniej możliwość wiary”.

Czym byłaby ta wiara? Nie wchodząc bliżej w teorię wiary, powiedzmy tyle: wiara jawi się jako wolne przejście w królestwo, w którym panuje całkiem swoista logika wolności; przejście wolne, to nie znaczy arbitralne. „Powiecie, że jest to prawdziwy saltus mortalis w tym przejściu od absolutnego nieukierunkowania do aktu wiary. To, co prawdziwe w tej obserwacji, to to, że przejście musi być uważane za całkowicie wolne, ale mówić o arbitralności, to traktować wiarę jako hipotezę, która zostaje w sposób nieusprawiedliwiony zaszczepiona na stanie wątpienia i obiektywnej nieokreśloności. Nie ma tu jednak niczego takiego. Wiara nie jest hipotezą $i$ to jest kapitalne. Wiara jest aktem, przez który duch wypełnia próżnię między 'ja' myślącym a 'ja' empirycznym, afirmując ich transcendentny związek; a raczej wiara jest aktem, przez który duch się tworzy, duch, a nie jedynie podmiot myślący, duch - rzeczywistość żywa i aktywna" (JM. s. 44 n.). Albowiem "odkrywam, że muszę stwierdzić [poser], iż stosunek 'mnie' jako myśli i jako woli do 'mnie' jako empirycznego nie jest stosunkiem przypadkowym. Muszę myśleć o jedności tego dualizmu p on ad wi ed zą" (JM. s. 6).

Jakże jednak w takim razie pojąć tę jedność? „Jest ona funkcją wolności, która jej c h c e” (JM. s. 6). Na tym „chce” nadbudowuje się dopiero teoria wiary; jest ona rozwinięciem „logiki wolności”, która jest swoistą logiką wartości i logiką woli. Jej nerwem jest przekonanie, że akceptacja wolnego ducha jest możliwa tylko $\mathrm{w}$ dialogu $\mathrm{z}$ wolnością Boga i jako uczestnictwo w niej. W ten sposób teoria wiary z I części Dziennika metafizycznego nawiązuje do teorii partycypacji z Fragmentów filozoficznych.

\section{KONKLUZJA}

Zbudowana na bazie krytyki racjonalistycznego idealizmu oraz scjentyzmu teoria poznania Marcela wprowadza koncepcję różnych poziomów zrozumiałości: od istnienia [egzystencji], które jest poniżej myśli refleksyjnej i dyskursywnej, aż do wiary, która jest ponad nią. W centrum tej hierarchii tkwi cogito jako akt myśli dyskursywnej.

Otóż w łonie cogito zarysowuje się szczególna sprzeczność. Obejmując 
całość pola możliwych poznań, oświetla ono różne poziomy zrozumiałości - w ich jedności - a więc zarówno „to, co ogólne” jak „to, co konkretne", w szczególności ja jako podmiot myśli ogólnej, oraz ja podmiot konkretności. Jednakże będąc samo podmiotem myśli ogólnej, cogito ustanawia od razu d u a li z m tych dwóch poziomów ja, interpretując je jako dualizm tego, co ogólne, i tego, co empiryczne, i nie mogąc zrozumieć ich pierwotnej jedności. Ale cogito jest w stanie cofnąć się do swojego własnego warunku możliwości i uchwycić siebie samo jako akt, d l a którego wszystkie dualizmy są dualizmami, a wszelka prawda -

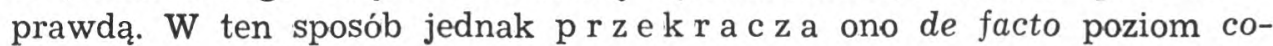
gito, przekracza siebie samego ku głębszemu poziomowi zrozumiałości. Odkrywa mianowicie, że skoro dualizmy i prawda są dla niego, to transcenduje je ono, jest więc wolne. Odkrywa „logikę wolności”, której pierwszym przejawem jest wola jedności, scalenia dualizmów, „zabliźnienia ran".

Jedność ta jednak - i to wskazuje, że mamy tu do czynienia $\mathrm{z}$ nowym poziomem zrozumiałości - jest możliwa tylko pod warunkiem, że nie jest przypadkowa, a więc, że jest sensowna. Tylko że sensowność ta nie leży już w kompetencji cogito, lecz — wiary. Teoria wiary jest badaniem warunków możliwości logiki wolności, która jest logiką najgłębiej aksjologiczną. Jej podstawową tezą jest twierdzenie, że wolność realizuje się $w$ całym swoim bogactwie jedynie jako indywidualny „duch" w łączności z wolnością Boga, który chciał mnie zanim ja mogłem zechcieć siebie.

Cały pierwszy okres filozofii Gabriela Marcela nosi na sobie bardzo silne piętno historyczne. Jest to nie tylko walka z pewnymi wersjami filozofii pokantowskiej, ale $\mathrm{w}$ ogóle $\mathrm{z}$ nowożytną koncepcją świadomości. W koncepcji tej świadomość jest nade wszystko (1) p o d m i o t e m wiedzy ogólnej, racjonalnej, odniesionej do równie racjonalnych przedmiotów, jak również (2) t wó r c ą tego, co racjonalne i co w ogóle poznawalne czy wręcz sensowne. Marcel przeciwstawia się tej koncepcji w imię tego co indywidualne, konkretne, oraz wymykające się poznaniu racjonalnemu i dlatego także pretensjom podmiotu do konstytuowania jego sensowności. Próbuje on podważyć tę koncepcję, ale w pierwszym okresie swej filozofii czyni to wciąż jeszcze wewnątrz niej. Dlatego to, co nie jest racjonalne w znaczeniu nowożytnym, jawi się tutaj po prostu jako niepoznawalne lub poza prawdą i fałszem. A jednak Marcel - co widać szczególnie w jego teorii wiary - toruje sobie drogę do określenia nowego typu zrozumiałości, która będzie domagała się od niego ni mniej ni wię- 
cej tylko całkowitego zrewidowania nowożytnej koncepcji świadomości. Próbę tej rewizji podejmie on już w II części Dziennika metafizycznego równolegle, a nawet wcześniej niż jego wielki niemiecki rówieśnik Martin Heidegger.

\section{LES FONDEMENTS EPISTEMOLOGIQUES DE LA FOI DANS LES PREMIERS ECRITS DE GABRIEL MARCEL}

\section{R és u m é}

Dans les tous premiers écrits - publiés en partie dans les Fragments philosophiques 1909-1914 Gabriel Marcel, un grand philosophe religieux contemporain, récuse l'idéalisme et le scientisme rationalistes qui étaient à l'honneur à la fin du $19 \mathrm{e}$ siècle, au nom de l'individuel et de l'incomparable, en particulier de l'unique expérience individuelle de l'homme.

Dans sa critique de l'idée de science absolue défendue en particulier par $\mathrm{He}-$ gel, Gabriel Marcel démontre l'impossibilité pour le rationalisme et l'idéalisme d'affirmer la réalité à la fois de l'infini et du fini, de l'absolu et de la pensée humaine. La science absolue est une chimère, car étant une contradiction en soi, elle n'est qu'un postulat impossible à réaliser d'une science toujours finie. C'est dans l'acte de connaître lui-même qui, étant la condition de possibilité de la connaisance, échappe à la connaissance, que Gabriel Marcel voit la sounce de ces contradictions. L'intuition peut cependant préhender cet acte comme une liberté participant à l'être. Sans cette participation, c'est-à-dire sans une ouverture foncière à l'être, aucune pensée ne serait possible. Mais en même temps, pour le philosophe, cette participation signifie au préalable la foi en Dieu.

A partir de sa critique de l'idéalisme et du scientisme, Gabriel Marcel formule dans la première partie du Journal métaphysique sa première théorie de la connaissance, théorie qui approfondit également les fondements de la philosophie de la foi esquissée dans la théorie de la participation proposée dans les Fragments philosophiques. Cette théorie de la connaissance consiste principalement à discerner plusieurs plans d'intelligibilité et plusieurs niveaux de fonctionnement de la conscience. Comme le niveau central s'avère être celui de cogito qui, étant la source de la pensée discursive et rationelle, comporte la passibilité de se comprendre en tant qu'acte et de transcender ainsi le plan rationnel, il se découvre par coséquent comme liberté. Celle-ci ve ut avant tout l'unification des dualismes introduits par la pensée discursive, dont le principal est celui du moi pensant et du moi empirique. Mais cette unification s'avère impossible sans une relation libre avec la liberté divine, car c'est seulement en tant que voulu par Dieu et partant plein de sens, que je peux accepter mon individualité empirique, et me constituer de cette façon comme esprit humain concret. 